\title{
O PRINCÍPIO DA IGUALDADE E A PENSÃO POR MORTE DO VIÚVO ANTES DA EDIÇÃO DA LEI 8.213/91
}

\section{PRINCIPLE OF EQUALITY AND DEATH PENSION BEFORE THE EDITION OF THE LAW 8.213/91}

\author{
Juliana Sibele Silveira Darde \\ Graduada em Ciências Jurídicas e Sociais pela \\ Universidadedo Vale do Rio dos Sinos. Especialização em \\ Direito Público pela Faculdade IDC.Procuradora \\ Municipal de Porto Alegre. \\ André Santos Chaves \\ Doutor e Mestre em Direito pela Universidade do Vale do \\ Rio dos Sinos.Procurador Municipal de Porto Alegre
}

Resumo: $\mathrm{O}$ tema abordado trata da igualdade de tratamento entre homens e mulheres na concessão da pensão por morte no Regime Geral de Previdência. A Constituição de 1988 instituiu no artigo $5 .^{\circ}$ que todos são iguais perante a lei, consagrando em diversos outros dispositivos a i- gualdade entre os cônjuges, bem como a igualdade entre homens e mulheres na concessão dos benefícios previdenciários. Além disso, a Lei Fundamental reconheceu proteção especial à família. Essas inovações trouxeram, ao longo do tempo, importantes reflexos para o direito pre- 
videnciário, que foi albergado pela Lei Fundamental. No entanto, no Regime Geral de Previdência, somente em 1991, com a edição da Lei de Benefícios (8.213/91) é que o direito previdenciário adequou-se às inovações trazidas pela Constituição. Assim, no período compreendido entre a data da promulgação da Constituição Federal e a promulgação da Lei $8.213 / 91$, algumas questões ficaram sem resposta, pairando muitas dúvidas a respeito do assunto e decisões divergentes em nossos Tribunais. Em especial, cite-se à do direito ou não do homem viúvo, não-inválido, a perceber o benefício da pensão por morte da esposa (segurada). Embora a Constituição de 1988 já assegurava a igualdade entre homens e mulheres, não havia lei específica reconhecendo este direito. É, portanto, o objeto deste trabalho analisar a diferenciação na concessão de pensão por morte aos cônjuges (homem e mulher), considerando o princípio da igualdade constitucional. Concluise que o homem (viúvo não-inválido), mesmo antes da edição da Lei 8.213/91, faz jus ao recebimento da pensão por morte, decorrente de óbito da esposa (segurada), visto ser inadmissível quaisquer tipos de discriminações na concessão de benefí- cio previdenciário em razão do sexo, já que homens e mulheres possuem os mesmos direitos e deveres desde a Constituição de 1988.

Palavras-chave: Constitucionalização. Direito Previdenciário. Pensão por morte. Igualdade entre homens e mulheres.

Resumen: El tema abordado trata de la igualdad de trato entre hombres y mujeres en la concesión de la pensión por muerte en el Régimen General de Previsión. La Constitución de 1988 estableció en el artículo 5 que todos son iguales ante la ley, consagrando en diversos otros dispositivos la igualdad entre los cónyuges, así como la igualdad entre hombres y mujeres en la concesión de los beneficios de la seguridad social. Además, la Ley Fundamental reconoció protección especial a la familia. Estas innovaciones trajeron, a lo largo del tiempo, importantes reflejos para el derecho previsional, que fue albergado por la Ley Fundamental. Sin embargo, en el Régimen General de Previsión, sólo en 1991, con la edición de la Ley de Beneficios (8.213 / 91) es que el derecho previsional se adecuó a las innovaciones traídas por la Constitución. Así, en el perío- 
do comprendido entre la fecha de la promulgación de la Constitución Federal y la promulgación de la Ley $8.213 / 91$, algunas cuestiones quedaron sin respuesta, parando muchas dudas sobre el asunto y decisiones divergentes en nuestros Tribunales. En particular, se cite a la del derecho o no del hombre viudo, no inválido, a percibir el beneficio de la pensión por muerte de la esposa (asegurada). Aunque la Constitución de 1988 ya asegura la igualdad entre hombres y mujeres, no había ley específica reconociendo este derecho. Es, por lo tanto, el objeto de este trabajo analizar la diferenciación en la concesión de pensión por muerte a los cónyuges (hombre y mujer), considerando el principio de la igualdad constitucional. Se concluye que el hombre (viudo no inválido), incluso antes de la edición de la Ley 8.213/91, justifica la recepción de la pensión por muerte, derivada de la muerte de la esposa (asegurada), ya que es inadmisible cualquier tipo de discriminación en la concesión De beneficio previsional en razón del sexo, ya que hombres y mujeres poseen los mismos derechos y deberes desde la Constitución de 1988.

Palabras-clave: Constitucionalización. Derecho de la Seguridad Social. Pensión por muerte. Igualdad entre hombres y mujeres

1. Introdução - 2. Noções gerais da Previdência Social - 3. A pensão por morte no Regime Geral de Previdência - 3.1 Conceitos introdutórios e proteção da morte no Direito Previdenciário - 3.2 A evolução legislativa da pensão por morte - 3.3 Requisitos para concessão da pensão por morte 3.4 Cessação da pensão por morte - 4. O princípio da igualdade entre homens e mulheres e a pensão do viúvo antes da edição da Lei 8.213/91 - 4.1 O princípio constitucional da igualdade - $4.2 \mathrm{~A}$ pensão por morte ao viúvo - 5 . Outras desigualdades verificadas na concessão de benefício da pensão por morte em razão do sexo e da idade - 6. A pensão do viúvo nãoinválido em outros regimes de Previdência - 7. Conclusão - 8. Notas - 9. Referências bibliográficas. 
REVISTA DA ESDM - 2016 - V.2 - N.04

\section{INTRODUÇÃO}

O tema a ser abordado neste trabalho trata da aplicação do princípio constitucional da igualdade na concessão da pensão por morte ao homem viúvo (não-inválido), reflexo importante da constitucionalização do Direito Previdenciário.

A Constituição Federal de 1988 inovou as Constituições anteriores em termos de seguridade social, dedicando um título à Ordem Social (Título VIII) e, inclusive, trazendo uma seção específica sobre Previdência Social.

A Carta Magna previu, dentre outras inovações, a igualdade entre homens e mulheres na concessão de benefícios previdenciários. No entanto, no artigo 59 da ADCT previu a criação de projeto de lei relativo à organização, custeio e benefícios, visando atualizar a legislação previdenciária, já que havia se instaurado uma nova ordem jurídica, baseada no Estado Democrático de Direito.

Posteriormente, em 1991, visando atender ao artigo 59 da ADCT, foram promulgadas as Leis 8.212 e 8.213/91, tratando do custeio da seguridade social e dos benefícios, respectivamente.

O princípio constitucional da igualdade trouxe diversas consequências jurídicas no Direito Previdenciário, tendo a Lei Previdenciária, em 1991, reconhecido o direito à pensão por morte ao homem viúvo, independente de invalidez ou da comprovação de dependência econômica. Também, igualou a idade dos dependentes - filhos e irmãos a filhas e irmãs - para fins de dependência previdenciária.

A Constituição de 1988 repercutiu diretamente no Direito Previdenciário. Os princípios por ela adotados, previstos no título específico da seguridade social e também os previstos nos Títulos I (Princípios Fundamentais) e II (Dos Direitos e Garantias Fundamentais) refletiram no direito à concessão dos benefícios, em especial, o princípio da igualdade, a dignidade da pessoa humana, a universalidade da cobertura e do atendimento, bem 
como à proteção especial à família.

O legislador na Constituição de 1988 trouxe diversos avanços à sociedade, como a proibição ao retrocesso social, o princípio da proteção à família, bem como a igualdade entre homens e mulheres, eliminando diferenciações e discriminações injustificáveis.

No entanto, as inovações em matéria previdenciária só foram efetivamente colocadas em prática, no Regime Geral de Previdência, após a edição da legislação específica, em 1991. No entanto, este foi um grande e rápido avanço. Cite-se, por exemplo, que no Estado do Rio Grande do Sul, até hoje, não ocorreu a atualização da legislação previdenciária e adequação à Constituição Federal, tendo se perpetuado no tempo a diferenciação no critério da concessão de benefício da pensão por morte a homens e mulheres. Portanto, mostra-se relevante analisar as consequências da igualdade trazida pela Constituição Federal e as regras de Direito Previdenciário.

\section{NOÇÕES GERAIS DA PREVIDÊNCIA SOCIAL}

A Previdência tem como vertente o trabalho, destinando-se a proteger os trabalhadores, e, tendo como objetivos a redistribuição da riqueza, a proteção contra os infortúnios da vida e contingências sociais. Ainda, importante salientar que é ramo próprio da ciência jurídica. (RIBEIRO, 2001, p. 81-82)

A implementação da Previdência Social no Brasil ocorreu por meio da Lei Eloy Chaves, que resultou no Decreto 4.682 de 1923. Antes disso, ora as questões previdenciárias eram tratadas no Direito Civil, ora no Direito do Trabalho. No entanto, somente com a Lei 3.807 de 1960, denominada LOPS, que ocorreu uma melhor sistematização das leis e decretos dentro de uma unidade, passando o Direito Previdenciário a ser reconhecido como ramo próprio. (RIBEIRO, 2001, p.82)

$\mathrm{O}$ art. $1 .^{\circ}$ da Lei 8.213/91 refere que: 
A Previdência Social, mediante contribuição, tem por fim assegurar aos seus beneficiários meios indispensáveis de manutenção, por motivo de incapacidade, desemprego involuntário, idade avançada, tempo de serviço, encargos familiares e prisão ou morte daqueles de quem dependiam economicamente.

Nesse sentido, a Previdência Social é um seguro social, de caráter contributivo, ou seja, é mantida com recursos de trabalhadores e de toda sociedade, objetivando propiciar meios de subsistência aos segurados ou seus dependentes, quando o segurado não puder obtê-los ou quando não for socialmente desejável (é o caso da velhice, invalidez, morte, maternidade etc.). (ROCHA e JÜNIOR, 2009, p.29)

No Brasil, considerando o princípio da solidariedade, previsto na Constituição Federal (art. 3. $\left.{ }^{\circ}, \mathrm{I}\right)$, o regime geral de Previdência Social consiste na transferência de renda entre indivíduos da mesma geração, com os trabalhadores em atividade financiando os inativos, o que chamamos de sistema de repartição simples.(ROCHA e JÜNIOR, 2009, p. 30)

Com relação aos princípios da seguridade social, alguns destes princípios têm natureza constitucional, enquanto outros são específicos da legislação previdenciária.

O artigo 194 da Constituição Federal traz os princípios aplicáveis à seguridade social. No texto constitucional, alguns dos princípios fundamentais da República Federativa do Brasil, previstos no art. $1 .^{\circ}$ e $2 .^{\circ}$ da Constituição Federal, também tem caráter previdenciário, quais sejam: cidadania, a dignidade da pessoa humana, baseado nos valores sociais do trabalho, visando a construção de uma sociedade livre, justa e solidária, com redução das desigualdades. Também, o princípio fundamental da solidariedade.

Já em relação aos princípios previdenciários propriamente ditos, temos 
a universalidade, a inscrição obrigatória e a proteção, a precedência de custeio, a seletividade e distributividade.(RIBEIRO, 2001, p. 96)

Quanto à filiação, tem-se que a mesma é obrigatória. Neste contexto, o trabalhador que estiver exercendo alguma das atividades elencadas no artigo 12 da Lei 8.212/91 ou no artigo 11 da Lei 8.213/91 terá vinculação obrigatória ao Regime Geral de Previdência, desde que não esteja amparado por regime próprio. (Duarte, 2004, p.21)

A filiação no Direito Previdenciário consiste na participação do segurado que exerce atividade remunerada ou daquele que voluntariamente opta pela filiação no Sistema de Previdência Social Pública. Em caso de segurado obrigatório, a filiação é automática.(RAMALHO, 2006, p. 67)

Assim, para os segurados que têm contrato de trabalho com anotação na CTPS, a filiação não ocorre mediante ato formal junto ao INSS. A anotação na CTPS do segurado já o torna filiado.(SANTOS, 2009, p. 81)

caso dos segurados facultativos, não basta a inscrição, há que ter, obrigatoriamente, pago a contribuição no prazo legal determinado na Lei 8.212/91- art. 30, inc. II. Caso contrário, não pode ser computado para efeito de carência visando a percepção dos benefícios previdenciários. (RAMALHO, 2006, p. 6768)

perante a Previdência Social.

$\S 4 .^{\circ}$ A perda da qualidade de segurado ocorrerá no dia seguinte ao do término do prazo fixado no Plano de Custeio da Seguridade Social para recolhimento da contribuição referente ao mês imediatamente posterior ao do final dos prazos fixados neste artigo e seusparágrafos.

Importante ainda, quanto às noções gerais, tendo em vista o tema deste 
artigo, dissertar acerca dos dependentes.

Carlos Alberto de Castro e João Batista Lazzari conceituaram dependentes da seguinte forma:

Dependentes são as pessoas que, embora não contribuindo para a Seguridade Social, a Lei de benefícios elenca como possíveis beneficiários do Regime Geral de Previdência Social - RGPS, fazendo jus às seguintes prestações: pensão por morte, auxílio reclusão, serviço social e reabilitação profissional.(CASTRO e LAZZARI, 2009, p. 213)

O art. 16 da Lei 8.213/91 prevê o rol de dependentes dos segurados da Previdência Social, nos seguintes termos:

Art. 16. São beneficiários do Regime Geral de Previdência Social, na condição de dependentes do segurado:

I - o cônjuge, a companheira, o companheiro e o filho não emancipado, de qualquer condição, menor de 21 (vinte e um) anos ou inválido ou que tenha deficiência intelectual ou mental que o torne absoluta ou relativamente incapaz, assim declarado judicialmente;

II - ospais;

III - o irmão não emancipado, de qualquer condição, menor de 21 (vinte e um) anos ou inválido ou que tenha deficiência intelectual ou mental que o torne absoluta ou relativamente incapaz, assim declarado judicialmente;

$\S 1 .^{\circ}$ A existência de dependente de qualquer das classes deste artigo exclui do direito às prestações os 
das classes seguintes.

$\S 2 .^{\circ}$ O enteado e o menor tutelado equiparam-se a filho mediante declaração do segurado e desde que comprovada a dependência econômica na forma estabelecida no Regulamento.

$\S 3 .{ }^{\circ}$ Considera-se companheira ou companheiro a pessoa que, sem ser casada, mantém união estável com o segurado ou com a segurada, de acordo com o $\$ 3 .^{\circ}$ do art. 226 da Constituição Federal.

$\S 4 .^{\circ} \mathrm{A}$ dependência econômica das pessoas indicadas no inciso I é presumida e a das demais deve ser comprovada.

Há no Regime Geral de Previdência duas espécies de dependentes, ou seja, os preferenciais ou presumidos (esses não necessitam comprovação da necessidade) e os dependentes sujeitos à comprovação da necessidade.

Em relação à presunção de dependência, a Lei 8.213/91 traz o cônjuge; o (a) companheiro(a); filhos não emancipados, menores de 21 anos; filhos inválidos ou que tenham deficiência intelectual ou mental que os tornem absoluta ou relativamente incapaz, assim declarado judicialmente. Frise-se que o inciso I do art. 16 foi alterado em 2011, por meio da Lei 12.470, para incluir a parte final do dispositivo que trata dos filhos que tenham deficiência intelectual ou mental.

Daniel da Rocha e José Baltazar, ao tratarem das noções gerais acerca da dependência no Direito Previdenciário, referiram que:

O rol do art. 16 limita a dependência previdenciária, de modo que o mero fato de alguém que não ostente a condição prevista na lei não será considerado dependente para fins previdenciários, ainda que dependa de fato do segurado. Quer dizer, a qualidade do dependente é determinada pela existência de depen- 
dência econômica, presumida ou real, e pela previsão no rol legal de dependentes. Desse modo, não ostenta a qualidade de dependente e não poderá habilitar-se, por exemplo, a receber pensão, o neto ou o sobrinho do segurado, ainda que dele dependa economicamente, por falta de previsão legal.(ROCHA $e$ JUNNIOR, 2009)

Quanto aos dependentes, importante ressaltar que, em relação ao cônjuge, mesmo que ambos desempenhem atividade econômica, serão considerados para fins previdenciários como dependentes um do outro. Isto ocorre porque o critério para caracterização de dependentes não é puramente econômico. (CASTRO e LAZZARI, 2009, p. 213)

Essa presunção de dependência decorre da história de Previdência Social, surgindo no tempo em que a mulher não trabalhava e que os filhos maiores de quatorze anos não colaboravam com a renda familiar. Assim, os membros da família stricto sensu possuem presunção absoluta de dependência do titular, não necessitando fazer qualquer comprovação de dependência, tendo direito ao benefício mesmo quando não necessite dele para subsistir. (MARTINEZ, 2003, p. 179)

\section{A PENSÃO POR MORTE NO REGIME GERAL DE PREVIDÊNCIA 3.1 CONCEITOS INTRODUTÓRIOS E PROTEÇÃO DA MORTE NO DIREITO PREVIDENCIÁRIO}

O art. 74 da lei 8.213/91 conceitua a pensão por morte no direito brasileiro.

Art. 74. A pensão por morte será devida ao conjunto dos dependentes do segurado que falecer, aposentado ou não, a contar da data: (Redação dada pela Lei n. ${ }^{\circ}$ 9.528, de 1997) 
I - do óbito, quando requerida até trinta dias depois deste; (Incluído pela Lei n. ${ }^{\circ}$ 9.528, de 1997)

II - do requerimento, quando requerida após o prazo previsto no inciso anterior; (Incluído pela Lei $n .^{\circ}$ 9.528, de 1997)

III - da decisão judicial, no caso de morte presumida.

A Previdência Social tem função essencialmente reparadora, por estar vinculada ao trabalho e com raízes no direito privado. Assim, serve para reparar os riscos que ameaçam a cessação ou redução de ganho do trabalhador. Nesse sentido, a morte é um evento que merece a proteção previdenciária, ao lado de outros riscos sociais. (DERZI, 2004, p. 36)

Para se atingir o objetivo que se propõe, a Previdência Social se utiliza de normas e princípios que se apresentam como resultado de um processo evolutivo. O art. 194 da Constituição que trata da Seguridade Social, abrange a Previdência Social, tendo como princípio a universalidade, de forma a dar cobertura a todas as situações e albergando a todos indistintamente.(DERZI, 2004,p. 36)

Quanto ao risco morte, no Regime Geral de Previdência Social, temos um enfoque jurídico, político (reconhecimento de direitos sociais) e econômico-social (distributividade de renda entre os membros da sociedade). Quanto ao enfoque jurídico, a Previdência Social adotou a concepção de seguro.(DERZI, 2004, p. 37)

A pensão por morte serve para proteger as pessoas que vivem às expensas do trabalhador. E, para determinados beneficiários, não necessita de comprovação de necessidade do dependente, ocasião em que a presunção de necessidade é absoluta. Nestas situações, o que importa é a relação jurídica entre o segurado e a Previdência Social (filiação e contribuição prévias) quando da ocorrência do evento para que o beneficiário faça jus ao benefício.(DERZI, 2004, p. 121-122)

A proteção constitucional do risco morte vem asse- 
gurada na Constituição de 1988, introdutora do Sistema de Seguridade Social, definido com um conjunto integrado de ações entre o Poder Público e a sociedade, para prover os serviços de saúde, previdência social e assistência social. Como parte integrante desse abrangente sistema de proteção, a Previdência Social tem finalidades específicas, desenvolvidas por meio de mecanismos próprios, rigorosamente tecidos pelo legislador constitucional.

Consoante o disposto no art. 201, "caput" da carta Magna, a Previdência Social integra um dos subsistemas constitucionais de Seguridade Social, a ser organizada na forma de regime geral, de caráter contributivo e de filiação obrigatória, observados critérios que preservem o equilíbrio financeiro e atuarial, e se destina a atender a cobertura dos eventos doença, invalidez, morte, idade avançada, maternidade, desemprego, salário-família e auxílio reclusão. (...)

É interessante observar que o legislador constitucional revelou, por duas vezes, preocupação em conferir proteção social ao risco morte: no art. 201, I, cita a morte como contingência protegida; no inciso V, confere o benefício específico da pensão por morte aos dependentes do segurado que falece, em valor nunca inferior ao salário mínimo. (art. 201, \$2. ${ }^{\circ}$ ).

Embora a Constituição já delineie o esboço constitucional dos benefícios, com seus requisitos indispensáveis, o próprio caput do art. 201 remete ao legislador infraconstitucional - "nos termos da lei..." - a tarefa de construir o tipo legal de cada benefício em 
particular, respeitado o mínimo constitucional tracejado.

Desse modo é a Lei 8.213/91 (Plano de Benefícios da Previdência Social) que se aloja a descrição do risco morte como fato relevante para o direito previdenciário, capaz de gerar, para os dependentes do segurado que falece, a proteção social prevista pelo regime geral, além dos demais requisitos legais indispensáveis à concessão dos benefícios.(DERZI, 2004, p. 123-124)

No entanto, frise-se que em caso de haver perda da qualidade do segurado, os dependentes não farão jus ao benefício da pensão por morte. No entanto, há uma única exceção, que ocorre quando o cidadão perdeu a qualidade de segurado após ter preenchido os requisitos para concessão da aposentadoria.(ROCHA e JÜNIOR, 2009, p. 300)

\subsection{A EVOLUÇÃO LEGISLATIVA DA PENSÃO POR MORTE}

O artigo 157, XVI da Constituição de 1946 já previa previdência para as consequências da morte.(MARTINS, 2007, p. 369)

Posteriormente, em 1960, com a edição da Lei 3.807, havia previsão expressa da pensão por morte nos artigos $36 \mathrm{a} 42$. $\mathrm{O}$ artigo 36 previa que a pensão por morte seria devida aos dependentes do segurado que, aposentado ou não, falecesse, após haver realizado 12 contribuições mensais. (MARTINS, 2007, p. 369)

E, somente em 1963, após a promulgação da Lei 4.214 é que a pensão por morte passou a ser devida aos dependentes de trabalhadores rurais.

Após, com a promulgação da Constituição de 1967, o artigo 158, XVI fazia menção à "previdência social nos casos de morte". E, a Emenda Constitucional n. ${ }^{\circ} 1$ de 1969 também era no mesmo sentido. (MARTINS, 2007, p. 369) 
Sérgio Pinto Martins, ao abordar a pensão por morte após a Constituição Federal de 1988, refere que:

A Constituição de 1988 estabelece que os planos de previdência social atenderão, mediante contribuições, à cobertura dos eventos morte (art. 201, I). $O$ inciso $V$ do mesmo artigo estabelece pensão por morte do segurado, homem ou mulher, ao cônjuge ou companheiro e dependentes, observado que nenhum benefício poderá ter valor inferior a um salário mínimo.

Os artigos 74 a 79 da Lei 8.213/91 versam sobre a pensão por morte.

Em sentido amplo, pensão é renda paga a certa pessoa durante toda a sua vida. (...) Pensão por morte éo benefício previdenciário pago aos dependentes em decorrência do falecimento do segurado.(MARTINS, 2007, p. 369-370)

\subsection{REQUISITOS PARA CONCESSÃO DA PENSÃO POR MORTE}

A pensão por morte do segurado é concedida quando ocorre a morte real e, também, nas hipóteses de morte presumida do segurado (mediante sentença declaratória de ausência ou, ainda, em caso de desaparecimento do segurado, decorrente de catástrofe, acidente ou desastre). No caso de morte presumida por declaração de ausência, a pensão é devida desde a data da declaração judicial de ausência. Já no caso de desaparecimento do segurado, a pensão será devida a contar da data da ocorrência, mediante prova hábil. (DIAS, 2008, p. 316)

Quanto à habilitação dos dependentes, tem-se que a inclusão ou exclusão de dependentes só produzirá efeito a partir da sua inscrição ou habilitação. E, em havendo vários pensionistas, ocorrerá o rateio do benefício entre todos, em partes iguais. E, quando o direito de um deles cessar, a sua cota reverterá em favor dos demais. (MARTINS, 2007, p. 372)

Quanto à inscrição do dependente, está prevista no artigo 22 do Decreto 3.048/99, com redação dada pelo decreto 4.079/2002, ou seja, a inscrição ocorrerá no momento em que o dependente fizer o requerimento do bene- 
fício, devendo apresentar os documentos a seguir relacionados: a) dependentes preferenciais: cônjuge e filhos: certidões de casamento e nascimento; b) companheira(o): documento de identidade e certidão de casamento com averbação de divórcio ou separação, quando um dos companheiros já tiver sido casado, ou certidão de óbito, se for o caso; c) equiparado a filho: certidão judicial de tutela e, se o dependente for enteado, deverá apresentar certidão de casamento do segurado e de nascimento do dependente. (CASTRO e LAZZARI, 2009, p. 222)

Já em caso de pais, deverá ser apresentada certidão de nascimento do segurado e documento de identidade dos pais. Se a pensão for para irmão, deverá apresentar certidão de nascimento. Ressalte-se que, para a inscrição destes dependentes, deverá ser comprovada a inexistência de dependentes preferenciais, na forma do artigo 24 do decreto 3.048/99 (mediante declaração firmada junto ao INSS). (CASTRO e LAZZARI, 2009, p. 222-223)

Melhor explicitando, em relação aos irmãos, se o segurado não deixou dependentes do núcleo familiar principal, nem pais, os irmãos menores de 21 anos ou inválidos e não emancipados possuem direito aos benefícios do dependente. (MARTINEZ, 2003, p. 180)

Também, para concessão da pensão aos dependentes, é necessária a verificação da qualidade de segurado na data do óbito. No entanto, o artigo 327 da IN 45/2010 prevê situação em que os dependentes farão jus à pensão por morte, mesmo que o óbito tenha ocorrido após a perda da qualidade de segurado. Vejamos:

Art. 327 Caberá a concessão de pensão aos dependentes mesmo que o óbito tenha ocorrido após a perda da qualidade de segurado, desde que:

I - o instituidor do benefício tenha implementado todos os requisitos para obtenção de uma aposentadoria até a data do óbito; $e$ 
II - fique reconhecido o direito, dentro do período de graça, à aposentadoria por invalidez, a qual deverá ser verificada por meio de parecer médico-pericial do INSS com base em atestados ou relatórios médicos, exames complementares, prontuários ou outros documentos equivalentes, referentes ao ex-segurado, que confirmem a existência de incapacidade permanente até a data do óbito.

$\S 1 .^{\circ}$ Para efeito do disposto no caput, os documentos do segurado instituidor serão avaliados dentro do processo de pensão por morte, sem resultar qualquer efeito financeiro em decorrência de tal comprovação.

$\S 2 .^{\circ}$ Para fins do disposto no inciso I do caput será observada a legislação da época em que o instituidor tenha implementado as condições necessárias para a aposentadoria.

\subsection{CESSAÇÃO DA PENSÃO POR MORTE}

As hipóteses de cessação da pensão por morte são as seguintes: morte do pensionista; ao pensionista menor de idade, quando completar 21 anos ou pela emancipação (exceto se for inválido); para o pensionista inválido, pela cessação da invalidez (nesse caso, será verificado em perícia médica da Previdência). (MARTINS, 2007, p. 373)

Em caso de pensão por morte presumida, se o segurado reaparecer, o benefício será cessado. No entanto, não haverá a necessidade de devolução dos valores recebidos pelos dependentes, exceto se comprovada má-fé. (DIAS, 2008, p. 316)

Importante registrar que a lei não prevê cessação da pensão por morte se o cônjuge contrair novo matrimônio. (MARTINS, 2007, p. 370) 


\section{O PRINCÍPIO DA IGUALDADE ENTRE HOMENS E MULHERES E A PENSÃO DO VIÚVO ANTES DA EDIÇÃO DA LEI 8.213/91 \\ 4.1 O PRINCÍPIO CONSTITUCIONAL DA IGUALDADE}

Princípios são normas que necessitam de interpretação para que se possa aplicar aos casos concretos, são dotados de elevada posição hierárquica e desempenham papel fundamental no sistema jurídico e político. Constitucionalizar os princípios significa fazer "a chave de todo sistema normativo". (BONAVIDES, 2001, p. 203-231)

Neste contexto, o princípio da igualdade, esculpido no artigo $5 .^{\circ}$, caput $^{1}$, da Constituição Federal, no título que trata dos direitos e garantias fundamentais, bem como no preâmbulo da Constituição ${ }^{2}$ deve ser entendido como valor supremo de nossa sociedade.

A igualdade, de acordo com Celso Antônio Bandeira de Mello, consiste em:

Não ser fonte de privilégios ou perseguições, mas instrumento regulador da vida social que necessita tratar equitativamente todos os cidadãos. Este é o conteúdo político-ideológico absorvido pelo princípio da isonomia e juridicizado pelos textos constitucionais em geral, ou de todo modo assimilado pelos sistemas normativos vigentes. (MELLO, 1993, p. 10)

E prossegue o autor (MELLO, 1993, p. 10-30), salientando que a igualdade não basta em si, pois nem todas as pessoas e situações são iguais de forma a merecer tratamento igualitário. Aí reside a "notória afirmação de Aristóteles, assaz de vezes repetida, segundo cujos termos a igualdade consiste em tratar igualmente os iguais e desigualmente os desiguais". No entanto, há critérios que devem ser observados para que não se utilize o fator diferenciador, ferindo o princípio da igualdade, quais sejam:

a) o fator discriminatório não pode ser tão específico a singularizar um 
ou alguns sujeitos;

b) o traço diferencial deve, necessariamente, residir na pessoa, coisa ou situação a ser discriminada, e não fora delas ("são incabíveis regimes diferentes determinados em vista de fatos alheios a elas").

Acerca do princípio da igualdade, Alexandre de Moraes salienta que:

A igualdade se configura como uma eficácia transcendente, de modo que toda situação de desigualdade persistente à entrada em vigor da norma constitucional deve ser considerada como não-recepcionada, se não demonstrar compatibilidade com os valores que a Constituição, como norma suprema, conclama.(MORAES, 2010,p.37)

\subsection{A PENSÃO POR MORTE AO VIÚVO}

Daniel da Rocha e José Baltazar, em sua obra, ao definirem cônjuges, trouxeram o seguinte conceito: "Cônjuges são o marido e a mulher, unidos pelo casamento. Desde a publicação da $\mathrm{CF} / 88$, que equiparou homens e mulheres em direitos e obrigações, no inciso I do artigo $5 .^{\circ}$, a qualidade de dependente foi estendida ao marido". (ROCHA e JÜNIOR, 2009, p. 29)

Anteriormente à promulgação da Lei 8.213/91, a organização da previdência estava prevista na Lei 6.439/77, posteriormente regulamentada pelo Decreto 83.080/79.

O Decreto 83.080/79, dentre outras questões, trazia o rol de dependentes do segurado da Previdência Social, no art.12, abaixo transcrito:

Art. 12. São dependentes do segurado:

I - A esposa, o marido inválido, a companheira mantida há mais de 5 (cinco) anos, os filhos de qualquer condição menores de 18 (dezoito) anos ou inválidose 
as filhas solteiras de qualquer condição menores de 21 (vinte e um) anos ou inválidas;

Assim, antes da Lei 8.213/91, era dependente da segurada da previdência apenas o marido inválido.

Marina Vasquez Duarte, ao tratar do dependente cônjuge e companheiro, em sua obra, salienta que a Constituição atual igualou homens e mulheres. Vejamos abaixo:

$A$ atual CF igualou os direitos entre homens e mulheres, bem como entre cônjuges e companheiros. Tudo que vale para um, deve valer para o outro. Cônjuge: marido e mulher, unidos pelo casamento. Tambémo marido é dependente da mulher, segundo este artigo. Pela legislação anterior (CLPS 84) o marido só seria dependente da mulher quando inválido. (Duarte, 2004,p.52)

Carlos Alberto Pereira de Castro e João Batista Lazzari, ao tratarem da pensão por morte, referiram que:

A pensão por morte éo benefício pago aos dependentes do segurado, homem ou mulher, que falecer, aposentado ou não, conforme previsão expressa no art. 201, V da CF, regulamentada pelo art. 74 da Lei do RGPS. Em face disso, considera-se direito irrenunciável dos beneficiários que fazem jus a ela. O STF tem decidido que a extensão automática da pensão ao viúvo, em decorrência do falecimento da esposa segurada urbana e rural, exige lei específica, tendo em vista as disposições inscritas no art. 195, caput e seu $\$ 5 .^{\circ}$ e art. 201, V da Constituição Federal. Nesse sentido, o RE 202.146/RS, Informativo STF de 
28/07/1999, em relação à segurada rural e o RE $n .^{\circ}$ 436.400-0/SC, julgado por despacho em 24/11/2004, em relação à segurada urbana. A regulamentação reclamada só ocorreu com o advento da Lei n. ${ }^{\circ} 8.213 /$ 91. (CASTRO, 2009, p. 623)

No entanto, grande dúvida paira sobre o assunto nos casos em que o marido não-inválido tenha ficado viúvo após a promulgação da Constituição Federal de 1988, porém antes do advento da Lei 8.213/91. A questão não é unânime, havendo interpretações diversas (há os que defendem a prevalência do princípio constitucional da igualdade para conceder a pensão por morte nesses casos e outros que defendem a prevalência da regra previdenciária vigente à época data do fato (óbito), bem como a necessidade da fonte de custeio).

Abaixo, segue decisão do STF, que aplicou o princípio da igualdade, concedendo pensão por morte ao viúvo de mulher falecida em 1990. Vejamos a ementa:

EMENTA: AGRAVO REGIMENTAL. PREVIDENCIÁRIO. REGIME GERAL DE PREVIDÊNCIA. PENSÃO POR MORTE. CÔNJUGE VARÃO. ÓBITO ANTERIOR AO ADVENTO DA LEI 8.213/91. PRINCÍPIO DA ISONOMIA. INCIDÊNCIA DA REDAÇÃO ORIGINAL DO ART. 201, V, DA CONSTITUIÇÃO. AUTOAPLICABILIDADE. ART. 195, S 5. ${ }^{\circ}$, DA CONSTITUIÇÃO. EXIGENCIA DE FONTE DE CUSTEIO. DESNECESSIDADE. Agravo regimental a que se nega provimento. (STF, RE 352. 744/SC, Relator: Min. Joaquim Barbosa, Data de julgamento: 01/03/2011, Fonte: www.stf.gov.br)

A decisão judicial colacionada trata de caso em que segurada (mulher) da Previdência faleceu no ano de 1990, época em que o esposo não constava 
na lei previdenciária como dependente de segurado. O STF entendeu que deveria ser concedida pensão por morte ao marido, não-inválido, embora o óbito da segurada fosse anterior à Lei 8.213/91, embasando a decisão no princípio constitucional da igualdade.

Embora a Constituição Federal já tivesse vigendo na época no óbito da segurada (1990), com menção expressa no art. 5. ${ }^{\circ}$, I, de que homens e mulheres são iguais em direitos e obrigações e, também, trazendo na seção III (Previdência Social), no art. 201, V, a igualdade entre homem e mulher na concessão da pensão por morte, a lei previdenciária ainda não trazia tal igualdade em seu texto.

Vejamos entendimento de Daniel Machado da Rocha e José Paulo Baltazar Júnior acerca da questão abordada na decisão do STF:

No que pertine aos dependentes com direito à pensão, havia discussão sobre a possibilidade da concessão da prestação para o companheiro ou o marido não-inválido quando o óbito da segurada se desse após o advento da Constituição Federal de 1988 e antes da entrada em vigor da atual Lei de Benefícios (Lei 8.213/91). A pertinência da questão reside em que, na data do óbito, o companheiro - assim como o marido não-inválido - não estava contemplado pela legislação previdenciária como dependente previdenciário (Lei 3.087/60, art. 11, com as alterações do Decreto-Lei 66/66 e da Lei 5.890/73).

No regime da lei atual, de acordo com o art. 16, são dependentes o cônjuge de qualquer sexo e o companheiro. Em linha de princípio, a concessão da pensão se rege pela lei vigente na data do óbito. (...) De todo o exposto, conclui-se que há direito ao benefício na situação enfocada, pois a negativa, apenas por ter $o$ 
óbito se verificado alguns meses antes da entrada em vigor da nova lei de benefícios, atenta contra a Constituição, sobre (sic) causar grave sentimento de injustiça (...). (ROCHA e JÜNIOR, 2006, p. 290)

Em decisão do TRF da 3. ${ }^{\text {a }}$ Região, a decisão foi pelo reconhecimento do direito à pensão ao viúvo não-inválido desde a promulgação da Constituição Federal de 1988, sob o argumento de eficácia plena do artigo 201 e, portanto, a presunção de dependência econômica do marido (não-inválido).

PREVIDENCIÁRIO - PENSÃO POR MORTE TRABALHADORA RURAL - VIÚVO NÃO INVÁLIDO NÃO FAZ JUS - LEGISLAÇÃO APLICÁVEL - SENTENÇA CONFIRMADA. 1. O fato idôneo previsto em lei, capaz de fazer nascer o direito à percepção do benefício de pensão por morte, só se verifica na data do óbito do segurado, devendo ser obedecido o princípio tempus regitactum, segundo o qual aplica-se a lei vigente à época de sua ocorrência. 2. Por força do art. 3.,$\$ 2 .^{\circ}$, da Lei Complementar $n .^{\circ}$ $11 / 71$, somente podiam ser tidas como dependentes dos trabalhadores rurais as pessoas assim definidas na Lei Orgânica da Previdência Social (Lei 3.807, de 26 de agosto de 1960) e em legislação posterior, em relação aos segurados do Sistema Geral de Previdência Social. Em outras palavras, tomando por base o art. 13 da Lei n. ${ }^{\circ} 3.807 / 60$, só à esposa - a par de outras pessoas mencionadas (marido inválido e filhos, nas condições assinaladas) - era lícita a presunção de depender do marido. Pessoas outras necessitam provar essa dependência. 3. Com efeito, somente a partir da norma inserta no artigo 201 da Constituição Federal vigente (de eficácia plena), a organi- 
zar a previdência social sob a forma de regime geral, de caráter contributivo e de filiação obrigatória, restou estabelecida a igualdade direitos à pensão por morte do segurado, homem ou mulher, ao cônjuge ou companheiro e dependentes, observado o valor mensal mínimo. 4. É de se aceitar, desse modo, a presunção de dependência econômica do marido (não-inválido) em relação à esposa (falecida) somente após a promulgação da Constituição Federal, posição adotada, posteriormente, com o advento da Lei n. ${ }^{\circ}$ 8.213/91 (artigo 16, parágrafo 4. ${ }^{\circ}$ ). 5. Apelo do autor improvido. 6. Sentença mantida. (grifo nosso.). ${ }^{3}$

Abordando o mesmo assunto, o TRF da $4 .{ }^{a}$ Região entendeu não ser devida a pensão por morte ao viúvo, por reger-se a pensão pela lei vigente ao tempo do óbito do segurado e, na data em que teria falecido a segurada, não havia previsão na lei previdenciária do viúvo (homem) não-inválido como sendo dependente. Vejamos abaixo:

PREVIDENCIÁRIO. PENSÃO POR MORTE DE ESPOSA. ÓBITO ANTERIOR À LC 11/71. Conquanto $o$ inciso $V$ do art. 201 da Constituição Federal de 1988 tenha estendido o direito à pensão por morte do segurado, homem ou mulher, ao cônjuge varão ou companheiro, tal dispositivo, consoante interpretação do Supremo Tribunal Federal (RE 204.193/RS, Tribunal Pleno, julg. em 30-05-2001, DJ 31-102002, e RE 204.735/RS, Tribunal Pleno, julg. em 3005-2001, DJ 28-09-2001), não era auto-aplicável e somente foi regulamentado pela Lei 8.213, de 24/07/ 
1991. Esta, por sua vez, incluiu o esposo no rol de dependentes passíveis de recebimento de pensão por morte, não se aplicando, todavia, às hipóteses em que o óbito ocorreu anteriormente a 05/04/1991, uma vez que os efeitos da referida Lei de Benefícios retroagiram a tal data, em razão de disposição expressa (art. 145). ${ }^{4}$

Também, em decisão da Turma Nacional de Uniformização de Jurisprudência dos Juizados Especiais Federais, datada de 21/11/2008, a questão foi decidida pela não-percepção do benefício ao viúvo não-inválido, cuja segurada faleceu antes da Lei 8.213/91, considerando o entendimento de que o benefício da pensão por morte é regido pelas normas em vigor à época do falecimento do segurado e, embasada no fato de que o marido nãoinválido não estava contemplado como dependente na legislação anterior à lei 8.213/91, não se podendo, portanto, aplicar a Lei 8.213/91 aos fatos geradores anteriores a sua edição e nem aplicar efeitos retroativos que não foram previstos pela lei. ${ }^{5}$

O INSS normatizou a questão no sentido de reconhecer o direito à pensão do viúvo não-inválido somente à partir da edição da Lei 8.213/91. O artigo 321 da IN 45/2010 refere que:

Art.: 321. Para óbitos ocorridos a partir de 5 de abril de 1991, é devida a pensão por morte ao companheiro e ao cônjuge do sexo masculino, desde que atendidos os requisitos legais.

Parágrafo único. Para cônjuge do sexo masculino, será devida a pensão por morte para óbitos anteriormente a essa data, desde que comprovada a invalidez, conforme o art. 12 do Decreto $n .^{\circ} 83.080$, de 1979.

No entanto, saliente-se que em relação à interpretação do Direito Previ- 
denciário, deve-se levar em conta os fundamentos e objetivos do Estado Democrático de Direito, em especial, a dignidade da pessoa humana (prevista como fundamento). Ainda, frise-se que a Constituição Federal, no art. 3. ${ }^{\circ}, \mathrm{IV}$, refere que é objetivo fundamental da República Federativa do Brasil "promover o bem de todos, sem preconceito de origem, raça, sexo, cor, idade e quaisquer outras formas de discriminação", não se admitindo qualquer interpretação da legislação previdenciária que acentue desigualdades e contrarie o princípio da dignidade da pessoa humana. (SANTOS, 2009, p. 9-12)

Quanto à interpretação constitucional das normas previdenciárias, vejamos as explanações de Marcus Oriane Gonçalves Correia e Érica Paula Barcha Correia:

Na verdade partimos de uma constatação óbvia de que a Constituição é que rege o sistema. A leitura, portanto, deve ser a partir da Constituição e não a partir dos atos normativos infraconstitucionais ou mesmo dos atos administrativos que, aparentemente, possuem efeito normativo. (...) Em direito de segurança social, especialmente previdência e saúde, há uma proliferação enorme de atos administrativos, o que é compreensível, na medida em que essas duas áreas de atuação do direito estão ligadas essencialmente ao direito administrativo. (...) O que se sugere é que façamos a leitura a partir da Constituição. Há uma dificuldade enorme, percebe-se, dos operadores de direito, na utilização do sistema constitucional. Muitas vezes estes esgotam as possibilidades nos atos administrativos, quando muitos chegam às leis ordinárias e, se restar fôlego, alguns ainda conseguem visitar o texto constitucional. Diríamos até mais, que existem muitas regras constantes da Lei de Benefícios e da Lei de Custeio da Previdência Social que estariam a indicar inconstitucionalidades. Por- 
tanto, a essência está no estudo da interpretação constitucional.(CORREIA,2007, p. 58-59)

Nesta ótica, a partir de 1988, o sistema de segurança social é originariamente constitucional. Neste contexto, a descoberta do termo constitucional deve se dar pelo modelo de interpretação constitucional, buscando a unidade política por meio dos princípios lá contidos. A interpretação constitucional, como sabemos, é uma interpretação de princípios. Assim, os direitos sociais devem ser colocados como direitos fundamentais e a dinâmica de interpretação desses direitos vai ser aquela que busca a unidade políticoconstitucional dentro do sistema. Neste sentido, os benefícios previdenciários estão ligados ao próprio direito à vida e à liberdade, sendo, portanto, direitos que compõem o conceito de previdência, ou seja, o direito fundamental previdenciário. (CORREIA,2007, p. 59-73)

\section{OUTRAS DESIGUALDADES VERIFICADAS NA CONCESSÃO DE BENEFÍCIO DA PENSÃO POR MORTE EM RAZÃO DO SEXO E DA IDADE}

A situação do viúvo não-inválido, antes da edição da Lei de Benefícios, em 1991, não é discriminação isolada. Verifica-se o não-reconhecimento ao direito de pensão ao companheiro homossexual neste mesmo período, mesmo após a promulgação da Constituição Federal de 1988. No entanto, a questão da união homoafetiva até hoje não é regulamentada por lei, porém foi reconhecido o direito pelo INSS ao seu recebimento, mediante a edição de instrução normativa em 2006, ou seja, mesmo sem a existência de lei (em sentido formal).

Posteriormente, o STF, no julgamento da ADI n. 4277 e ADPF n. ${ }^{\circ} 132$, pacificou o reconhecimento da união homoafetiva para concessão da pensão por morte. No entanto, sem nenhuma alteração legislativa até o momento.

Nesta linha de raciocínio, importante ressaltar ainda que, no Brasil, não se admite o casamento civil entre pessoas do mesmo sexo. Do mesmo mo- 
do, a união estável do artigo $226, \S 3 .^{\circ}$ da $\mathrm{CF} / 88$ também indica que a união reconhecida pelo Estado é somente entre homem e mulher (pessoas do sexo oposto). (MARTINEZ, 2003, p. 181) E, em que pese o CNJ ter editado Portaria sob o n. ${ }^{\circ} 175$, admitindo o casamento homossexual, esta decisão não tem força de lei, em que pese obrigar os cartórios de registros civis a proceder ao casamento de pessoas do mesmo sexo. Ademais, no julgamento da $\mathrm{ADI}$ e da ADPF anteriormente citadas, embora tenha sido ditada a redação do art. 1723 do Código Civil de 2002 em consonância com a Constituição Federal, alargando-se a interpretação do conceito de entidade familiar, não há alteração legislativa.

Neste sentido, em termos previdenciários, não há lei que ampare o recebimento da pensão por morte ao companheiro do mesmo sexo. Deste modo, a impossibilidade de concessão da pensão por morte ao viúvo nãoinválido, sob o argumento do princípio da legalidade acaba não se sustentando de forma absoluta.

A Lei Básica de Benefícios até 28/04/1995 admitia que o segurado designasse qualquer pessoa como seu dependente, tendo como requisito apenas a limitação de idade (de 21 a 60 anos). No entanto, com a edição da Lei 9.032/95, não foi mais possível fazer esta designação, ou seja, a possibilidade de designação de dependentes previdenciários deixou de existir. Deste modo, a designação de dependente do mesmo sexo, decorrentes de uniões homoafetivas, mesmo que na condição de terceiro dependente, foi ceifada. (MARTINEZ, 2003, p. 181).

No entanto, em 27/07/2005, foi proferida decisão pelo Tribunal Regional Federal da 4. ${ }^{\mathrm{a}}$ Região, na apelação n. ${ }^{\circ}$ 2000.71.009347-0/RS, confirmando a sentença de $1 .^{\circ}$ grau da ação civil pública, com abrangência nacional, obrigando a inscrição pelo INSS de companheiros homossexuais como dependentes do Regime Geral de Previdência Social. Vejamos ementa da decisão: 
CESSO CIVIL. AÇÃO CIVIL PÚBLICA.

CABIMENTO. MINISTÉRIO PÚBLICO. LEGITIMIDADE. ABRANGÊNCIA NACIONAL DA DECISÃO. HOMOSSEXUAIS. INSCRIÇÃO DE COMPANHEIROS COMO DEPENDENTES NO REGIME GERAL DE PREVIDÊNCIA SOCIAL.

1. Possui legitimidade ativa o Ministério Público Federal em se tratando de ação civil pública que objetiva a proteção de interesses difusos e a defesa de direitos individuais homogêneos.

2. Às ações coletivas não se nega a possibilidade de declaração de inconstitucionalidade incidenter tantum, de lei ou ato normativo federal ou local.

3. A regra do art. 16 da Lei $n .^{\circ} 7.347 / 85$ deve ser interpretada em sintonia com os preceitos contidos na Lei n. ${ }^{\circ}$ 8.078/90 (Código de Defesa do Consumidor), entendendo-se que os limites da competência territorial do órgão prolator, de que fala o referido dispositivo, não são aqueles fixados na regra de organização judiciária, mas sim, aqueles previstos no art. 93 do CDC.

4. Tratando-se de dano de âmbito nacional, a competência será do foro de qualquer das capitais ou do Distrito Federal, e a sentença produzirá os seus efeitos sobre toda a área prejudicada.

5. O princípio da dignidade humana veicula parâmetros essenciais que devem ser necessariamente observados por todos os órgãos estatais em suas respectivas esferas de atuação, atuando co- 
mo elemento estrutural dos próprios direitos fundamentais assegurados na Constituição.

6. A exclusão dos benefícios previdenciários, em razão da orientação sexual, além de discriminatória, retira da proteção estatal pessoas que, por imperativo constitucional, deveriam encontrarse por ela abrangidas.

7. Ventilar-se a possibilidade de desrespeito ou prejuízo a alguém, em função de sua orientação sexual, seria dispensar tratamento indigno ao ser humano. Não se pode, simplesmente, ignorar a condição pessoal do indivíduo, legitimamente constitutiva de sua identidade pessoal (na qual, sem sombra de dúvida, se inclui a orientação sexual), como se tal aspecto não tivesse relação com a dignidade humana.

8. As noções de casamento e amor vêm mudando ao longo da história ocidental, assumindo contornos e formas de manifestação e institucionalização plurívocos e multifacetados, que num movimento de transformação permanente colocam homens e mulheres em face de distintas possibilidades de materialização das trocas afetivas e sexuais.

9. A aceitação das uniões homossexuais é um fenômeno mundial - em alguns países de forma mais implícita - com o alargamento da compreensão do conceito de família dentro das regras já existentes; em outros de maneira explícita, com a modificação do ordenamento jurídico feita de modo a abarcar legalmente a união afetiva entre pessoas do mesmo se$x o$. 
10. O Poder Judiciário não pode se fechar às transformações sociais, que, pela sua própria dinâmica, muitas vezes se antecipam às modificações legislativas.

11. Uma vez reconhecida, numa interpretação dos princípios norteadores da constituição pátria, a união entre homossexuais como possível de ser abarcada dentro do conceito de entidade familiar e afastados quaisquer impedimentos de natureza atuarial, deve a relação da Previdência para com os casais de mesmo sexo dar-se nos mesmos moldes das uniões estáveis entre heterossexuais, devendo ser exigido dos primeiros o mesmo que se exige dos segundos para fins de comprovação do vínculo afetivo e dependência econômica presumida entre os casais (Art. 16, I, da Lei n. ${ }^{\circ} 8.213 / 91$ ), quando do processamento dos pedidos de pensão por morte e auxílio-reclusão. ${ }^{6}$

A decisão acima referida fundamenta o direito de concessão à pensão por morte a dependentes do mesmo sexo nos princípios da igualdade, da dignidade da pessoa humana, no reconhecimento da transformação da família ao longo do tempo (referindo-se que a família se constitui por laços de afetividade e necessidades mútuas).

O INSS, na IN 25/2000, quando regulou os procedimentos para concessão da pensão por morte a companheiros homossexuais, previu a necessidade de comprovação da união estável e dependência econômica, ou seja, não considerou o companheiro homossexual como dependente presumido. Porém, em 2003, com a edição da IN 95/03, o órgão previdenciário, ao tratar do assunto, referiu que "o companheiro ou companheira homossexual de segurado inscrito no RGPS passa a integrar o rol dos dependentes e, desde que comprovada a união estável, concorrem, para fins de pensão 
por morte e de auxílio-reclusão, com os dependentes preferenciais de que trata o inciso I do Art. 16 da Lei 8.213/91, para óbitos ocorridos a partir de 05 de abril de 1991, ou seja, mesmo tendo ocorrido anteriormente à data da decisão judicial proferida na ação civil pública n. ${ }^{\circ}$ 2000.71.00.009347-0. Nesta instrução normativa, portanto, não se fez referência à necessidade de comprovação de dependência econômica.(DUARTE, 2004, p. 57)

Mais tarde, a questão foi analisada pela Advocacia-Geral da União, no Parecer 38/2009/ DRM/DENOR/CGU/AGU, tendo sido consolidado o posicionamento de que os Artigos 16, I, $\$ 3 .^{\circ}$ e $76, \$ 1 .^{\circ}$, ambos da Lei 8.213/91, deveriam ser interpretados de forma a abranger a união estável entre pessoas do mesmo sexo. E, dois anos mais tarde, em 2011, a CONJUR-MPS/ CGU/ AGU, no parecer 770/2011, fundamentada no reconhecimento pelo STF da "entidade familiar" formada por pessoas do mesmo sexo, desde que comprovada a união estável (pública, contínua e duradoura) e também na Portaria MPAS 513/2010, firmou entendimento no sentido de reconhecer a união estável homoafetiva como entidade familiar para fins civis e previdenciários. $^{7}$

Embora tenha havido o reconhecido pelo INSS do direito à pensão do dependente homossexual, por decisão judicial e com base em atos administrativos emanados pelo órgão (portaria e instrução normativa), pertinente que se façam as seguintes considerações:

Aqui se deve ter o cuidado de observar que os atos de indole administrativa - incluindo decretos, portarias, ordens de serviço - submetem-se aos rigores legais. Assim, jamais eles podem dispor de forma contrária à lei, pois se subjugam, no direito administrativo, ao seu império, em vista de vigorar nesse ramo o princípio da legalidade.

Igualmente, se qualquer ato de natureza administrativa - decretos, portarias, ordens de serviço etc- dis- 
puser de forma contrária à lei, impondo novas obrigações e mesmo novos direitos para o administrado deve ser desconsiderado, valendo a disposição legal. (CORREIA, 2007, p. 55)

Neste contexto, poderíamos entender que, se um ato normativo emanado pelo órgão previdenciário criou um novo direito, não previsto pela lei, não seria devida à pensão nestas situações, já que os companheiros homossexuais não são dependentes pelo rol da Lei 8.213/91. No entanto, importante referir que a garantia ao recebimento do benefício, independente da edição de qualquer ato normativo, já estaria assegurada pela própria Constituição Federal de 1988. Portanto, nessa situação, bem como no caso do viúvo não-inválido, o recebimento da pensão por morte se justificaria pela aplicação do sistema de segurança social a partir de 1988.

Embora a concessão da pensão por morte aos dependentes do mesmo sexo não esteja prevista em lei específica, as uniões homoafetivas não poderiam ficar desprotegidas, assim como os viúvos não-inválidos. Independente do sexo da pessoa e/ou da escolha do companheiro para a formação de uma família, os princípios constitucionais da igualdade, da dignidade da pessoa humana e o da universalidade da cobertura e do atendimento (Art. 194, I, da CF/88) devem ser observados, sob pena de violação aos direitos fundamentais do indivíduo. Neste sentido, qualquer discriminação decorrente da orientação sexual ou do sexo da pessoa é inconstitucional ou não recepcionada pela Constituição (em caso de lei anterior a sua promulgação).

Outra questão relevante trata da diferenciação que havia no tratamento entre filhos e filhas e irmãos e irmãs como dependentes do segurado, ou seja, antes da promulgação da Lei 8.213/91, se os irmãos ou filhos (não-inválidos) fossem do sexo masculino seria dependente até os 18 anos. Já as irmãs e filhas (não-inválidas), se solteiras, seriam dependentes até os 21 anos de idade.

A Lei 3.807/60 (LOPS), no Artigo 11, previa que:

Art 11. Consideram-se dependentes do segurado, para os efeitos desta lei: 
I - a espôsa, o marido inválido, os filhos de qualquer condição, quando inválidos ou menores de 18 (dezoito) anos, as filhas solteiras de qualquer condição, quando inválidas ou menores de 21 (vinte e um anos); (...)

III - os irmãos inválidos ou menores de 18 (dezoito) e as irmãs solteiras, quando inválidas ou menores de 21 (vinte e um) anos.

O Decreto 60.501/ 67, que aprovou nova redação do Regulamento Geral da Previdência Social (Decreto 48.959/60), previa nos Artigos 13 e 23 que irmãos e filhos (sexo masculino) seriam dependentes até os 18 anos de idade e que as irmãs e filhas solteiras (sexo feminino) seriam dependentes do segurado até os 21 anos de idade. Vejamos abaixo:

Art. 13. Consideram-se dependentes do segurado, para os efeitos deste Regulamento:

I - A esposa, o marido inválido, os filhos de qualquer condição menores de 18 (dezoito) anos ou inválidos, e as filhas solteiras de qualquer condição, menores de 21 (vinte e um) anos ou inválidas;

II - A pessoa designada que, se do sexo masculino, só poderá ser menor de 18 (dezoito) anos ou maior de 60 (sessenta) anos ou inválida;

III - Opai inválido e a mãe;

IV - Os irmãos de qualquer condição menores de 18 (dezoito) anos ou inválidos, e as irmãs solteiras de qualquer condição, menores de 21 (vinte e um) anos ou inválidas.

Art 23. A perda da qualidade de dependente ocorrerá: 


\section{$(\ldots)$}

$V$ - para os filhos e os a eles equiparados pelo $\$ 1 .^{\circ}$ do Art. 13, os irmãos e o dependente menos designado, ao completarem 18 (dezoito) anos de idade, salvo se inválidos;

$V I$ - para as filhas e as a elas equiparadas, as irmãs e a dependente menor designada, solteiras, ao completarem 21 (vinte e um) anos de idade, salvo se inválidas;

O Decreto 60.501/67 foi revogado pelo Decreto $72.771 / 73$.

O Decreto $72.771 / 73$ previa no Artigo 13 que:

Art 13. São dependentes do segurado, para os efeitos deste Regulamento:

I - a esposa, o marido inválido, a companheira mantida há mais de 5 (cinco) anos, os filhos de qualquer condição menores de 18 (dezoito) anos ou inválidos, e as filhas solteiras de qualquer condição menores de 21 (vinte e um) anos ou inválidas; (...)

O Decreto 3048/99, posteriormente, revogou o Decreto 72.771/73.

No entanto, a Lei 8.213/91, em seu texto original, já previu como dependente o filho e o irmão do segurado, menor de 21 anos, acabando com a diferenciação entre filhos e irmãos em razão do sexo.

Art. 16. São beneficiários do Regime Geral de Previdência Social, na condição de dependentes do segurado:

I - o cônjuge, a companheira, o companheiro e o filho, de qualquer condição, menor de 21 (vinte e um) anos ou inválido; 
III - o irmão, de qualquer condição, menor de 21 (vinte e um) anos ou inválido;

Porém, o Artigo 5. ${ }^{\circ}$ da Constituição Federal de 1988 já reconhecia a igualdade de todos perante a lei. Assim, desde a promulgação da Constituição de 1988, qualquer discriminação em relação ao sexo não estaria recepcionada. E, não bastasse o princípio da igualdade, o Artigo 1. ${ }^{\circ}$ da Carta Magna também previa o princípio da dignidade da pessoa humana como fundamento da República Federativa do Brasil. E, o Artigo 3. ${ }^{\circ}$ definiu a promoção do bem de todos, sem preconceito de raça, origem, cor, sexo, idade e quaisquer outras formas de discriminação como objetivo fundamental da República Federativa do Brasil.

O Capítulo VII da Constituição Federal também reconheceu a proteção do Estado em relação à família, tratando igualmente pais e filhos. Vejamos abaixo:

Art. 226. A família, base da sociedade, tem especial proteção do Estado.

(...)

$\S 4 .^{\circ}$ - Entende-se, também, como entidade familiar a comunidade formada por qualquer dos pais e seus descendentes.

Neste sentido, os avanços trazidos pela Constituição Federal de 1988, em especial, a proteção especial à família e a igualdade entre homens e mulheres, não justificam a existência de critérios diferenciadores entre filhos e filhas, irmãos e irmãs na concessão de benefícios previdenciários. Assim, qualquer critério baseado simplesmente na idade e/ou sexo é norma que retrocede o reconhecimento e a proteção conferidos pela Constituição, não sendo objetiva e razoável tal discriminação.

\section{A pensão do viúvo não-inválido em outros regimes de Previdência}

No Município de Porto Alegre, foi criado, em 2001, o PREVIMPA como 
REVISTA DA ESDM - 2016 - V 2-N.04

órgão gestor da Previdência dos seus servidores. Anteriormente, a Previdência do servidores públicos estatutários era responsabilidade do Montepio dos Funcionários do Município de Porto Alegre.

A legislação previdenciária atual do Município de Porto Alegre é bem avançada, havendo inclusive previsão legal expressa do direito ao recebimento de pensão por morte aos companheiros do mesmo sexo. Os cônjuges e companheiros, independentemente do sexo, são dependentes dos segurados (Artigo 25, I da LC 478/2002). No Regime Próprio de Previdência dos Servidores Públicos Municipais de Porto Alegre, a dependência econômica é presumida em relação aos seus cônjuges e companheiros. Vejamos abaixo:

Art. 25. São dependentes dos segurados do RPPS:

I - o cônjuge, a companheira, o companheiro e o filho não-emancipado de qualquer condição, menor de 21 (vinte e um) anos ou inválido;

(...)

$\S 5 .^{\circ}$ Considera-se companheira ou companheiro a pessoa que mantenha união estável com o segurado ou segurada.

$\S 6 .^{\circ}$ Considera-se união estável aquela verificada entre o homem e a mulher como entidade familiar, quando forem solteiros, separados judicialmente ou de fato, divorciados ou viúvos, ou tenham prole em comum, enquanto não se separarem.

$\S 70^{\circ}$ Considera-se também companheiro ou companheira, para fins de benefícios previdenciários, a pessoa do mesmo sexo do segurado que com ele mantém relacionamento estável, cujo vínculo será comprovado na forma disciplinada em regulamento.

$\S 8 .^{\circ}$ A dependência econômica das pessoas indica- 
das no inciso I é presumida e a das demais deve ser comprovada.

Com relação à legislação dos servidores do Estado do Rio Grande do Sul, até hoje não há previsão expressa da concessão de pensão por morte ao viúvo não-inválido.

A Lei 7.672/82 prevê que são dependentes do segurado:

Art. 9. ${ }^{\circ}$ - Para os efeitos desta lei, são dependentes do segurado:

I - a esposa; a ex-esposa divorciada; - vetado -; os filhos de qualquer condição enquanto solteiros e menores de dezoito anos, ou inválidos, se do sexo masculino, e enquanto solteiros e menores de vinte e um anos, ou inválidos, se do sexo feminino;

II - a companheira, mantida como se esposa fosse há mais de cinco anos, desde que se trate de solteira, viúva, desquitada, separada judicialmente ou divorciada, e solteiro, viúvo, desquitado, separado judicialmente ou divorciado seja o segurado.

$\S 5 .^{\circ}$ - Os dependentes enumerados no item I deste Artigo, são preferenciais e a seu favor se presume a dependência econômica; os demais comprová-la-ão naforma desta lei.

Art. 10 - A companheira como tal definida nesta lei concorre com ofilho, com a esposa do segurado, se esta estava judicialmente dele separada, e com a exesposa dele divorciada, desde que ambas percebam pensão alimentícia.

$\S 10^{\circ}$ - As pessoas referidas nos itens II, III e IV do 
art. 9. ${ }^{\circ}$ concorrem entre si se designadas pelo segurado.

$\S 2 .^{\circ}$ - vetado.

$\S 3 .^{\circ}$ - vetado.

Art. 11 - A condição de companheira, para os efeitos desta lei, será comprovada pelos seguintes elementos, num mínimo de três conjuntamente:

a) teto comum;

b) conta bancária conjunta;

c) outorga de procuração ou prestação de garantia real ou fideijussória;

d) encargos domésticos;

e) inscrição em associação de qualquer natureza, na qualidade de dependente do segurado;

f) declaração como dependente, para os efeitos do Imposto de Renda;

g) qualquer outra prova que possa constituir elemento de convicção.

Parágrafo único - A existência de filho em comum dispensa a exigência de cinco anos de convívio more uxório, desde que este persista até o óbito do segurado.

Art. 12 - Na falta de dependentes enumerados no Art. 9. ${ }^{\circ}$, o segurado poderá designar como beneficiário pessoa que comprovadamente viva sob sua dependência, exceto quando se tratar de Pecúlio Facultativo.

$\S 1 .^{\circ}$ - Só poderão ser designados na forma deste 
artigo pessoas do sexo masculino, se menores de dezoito ou maiores de sessenta anos ou inválidos e pessoas do sexo feminino se menores de vinte e um ou maiores de cinquenta e cinco anos ou inválidos. (grifos nossos)

Pela análise da legislação do Instituto de Previdência do Rio Grande do Sul, percebe-se que a lei é anterior à Constituição Federal e o legislador não acompanhou a evolução constitucional e social dos últimos tempos. A mulher (viúva de segurado) recebe proteção do Estado, como se, nos dias atuais, o homem ainda fosse o único provedor do sustento da família. A proteção conferida ao homem viúvo em 1991, pelo regime geral de previdência e, em 1988, com a Constituição Federal, ainda não foi reconhecida em âmbito estadual (Regime Previdenciário Próprio).

Vejamos algumas decisões judiciais sobre o assunto:

PREVIDENCIÁRIO. PENSÃO POR MORTE. INCLUSÁO DE EX-CÔNJUGE INVÁLIDO DE SERVIDORA ESTADUAL COMO DEPENDENTE PREVIDENCIÁRIO. POSSIBILIDADE. DEPENDÊNCIA ECONÔMICA COMPROVADA. A dependência econômica é condição indispensável para o percebimento da pensão previdenciária pelo viúvo segurado. Tendo em vista a comprovação da invalidez, bem como da dependência econômica pelo autor, configurado está o direito ao percebimento do benefício previdenciário de pensão por morte junto ao IPERGS. Apelo desprovido. ${ }^{8}$

PENSÃO POR MORTE DA SERVIDORA. VIÚVO INVÁLIDO. ART. 9. ' I, 7.672/82. MATÉRIA ATINENTE À SUBCLASSE PREVIDÊNCIA PÚBLI$C A$. Pretensão de viúvo em receber pensão, em razão da morte da servidora, por se tratar de dependente 
da segurada, nos termos do Art. 9. ${ }^{\circ}$ I, da Lei 7.672/ 82. Matéria que se insere na subclasse previdência pública, cuja competência para julgamento é de uma das Câmaras integrantes dos Colendos $1 .^{\circ}$ e $11 .^{\circ}$ Grupos Cíveis, na forma do Art. 11, I, b, Resolução n. ${ }^{\circ}$ 01/98. Declinaram da Competência. Unânime. ${ }^{9}$

PREVIDÊNCIA SOCIAL. PENSÃO POR MORTE DE SEGURADA DO IPERGS. MARIDO COMO BENEFICIÁRIO. POSSIBILIDADE. UMA VEZ QUE A CONSTITUIÇÃO FEDERAL, ATRAVÉS DE SEUS ARTS. 5, I E PAR-1, 6, 201, V E 226 E PAR-5, AO TRATAR DOS DIREITOS E GARANTIAS FUNDAMENTAIS, COM EXTENSÃO A PREVIDÊNCIA SOCIAL E A FAMÍLIA, ESTABELECE A IGUALDADE DE DIREITOS E OBRIGAÇÕES ENTRE O HOMEM E A MULHER, NÃO PODE O MARIDO SER IMPEDIDO DE CONSTAR COMO DEPENDENTE DE SEGURADA, PERANTE O IPERGS. RESTRIÇÃO DA LEI ESTADUAL N. ${ }^{\circ} 7672 / 82$, SO ADMITINDO, COMO DEPENDENTE, O MARIDO "INVÁLIDO" NÃO SE COADUNA COM A CONSTITUIÇÃO FEDERAL, RESTANDO, NESSE PONTO, DERROGADA. APLICAÇÃO IMEDIATA DE NORMAS DEFINIDORAS DOS DIREITOS E GARANTIAS FUNDAMENTAIS. A PENSÃO POR MORTE DA SEGURADA, A SER ALCANÇADA AO BENEFICIÁRIO, DEVE CORRESPONDER A TOTALIDADE DOS VENCIMENTOS OU PROVENTOS DE TAL SEGURADA, POR APLICAÇÃO IMEDIATA TAMBÉM DO ART-40, PAR-5, DA CF, EM CONSONÂNCIA COM O ART-4EO ART-37, XI, DA MESMA, NA REDAÇÃO ANTERIOR AS EMENDAS 
CONSTITUCIONAIS NOS. 19/98 E 20/98. ESTAS, ALIAS, NÃO LEVAM A OUTRA CONCLUSÃO. EMBARGOS INFRINGENTES ACOLHIDOS. VOTOS VENCIDOS. ${ }^{10}$

As decisões judicias referentes à concessão ou não da pensão por morte ao viúvo não-inválido não são unânimes. No entanto, em breve, poderemos ter uma resposta do STF para os casos em que o viúvo não comprove a invalidez ou dependência econômica da mulher (segurada falecida). No referido Tribunal está pendente o julgamento do RE 659424, tendo como uma das partes o Instituto de Previdência do Estado do Rio Grande do Sul. Em outubro de 2011, foi reconhecido que a causa tem repercussão geral, considerando que irá decidir acerca dos requisitos legais para a concessão de pensão por morte aos cônjuges de ex-servidoras públicas. Desde junho de 2015, o processo está concluso com o relator, tendo sido admitido o SINAPERGS (Sindicato dos Servidores Públicos Aposentados e Pensionistas do Estado do Rio Grande do Sul como amicus curiae). ${ }^{11}$

Neste processo, o Instituto de Previdência do Estado do Rio Grande do Sul (Ipergs) recorreu da decisão do Tribunal de Justiça Gaúcho que concedeu ao viúvo o benefício da pensão por morte, com base no princípio da isonomia. Portanto, espera-se uma decisão da Corte Máxima sobre a matéria, de forma a uniformizar a questão, evitando que ocorra tratamento diferenciado na concessão ou não-concessão de pensões àqueles viúvos que pleiteiam o benefício.

Ressalte-se que em 2008, o STF, ao julgar o recurso extraordinário, em que figurava como uma das partes o Instituto de Previdência do Estado de Minas Gerais, entendeu pela inconstitucionalidade do dispositivo que condicionava o recebimento da pensão por morte pelo viúvo de servidora pública estadual à comprovação da invalidez. Naquela ocasião, a decisão do STF foi no sentido da concessão de benefício ao viúvo não-inválido. Vejamos ementa da decisão:

PENSÃO - VIÚVO - LEGISLAÇÃO DO ESTADO

DE MINAS GERAIS - INVALIDEZ DO MARIDO - 
CONDIÇÃO PARA PERCEPÇÃO DO BENEFÍCIO

- OFENSA AO PRINCÍPIO DA ISONOMIA - INCONSTITUCIONALIDADE - PRECEDENTES DO PLENÁRIO. Ao julgar o Recurso Extraordinário n. ${ }^{\circ}$ 385.397-0/MG, o Plenário assentou ofender o princípio da isonomia legislação local que prevê exigência para o viúvo de servidora pública ter direito à pensão. ${ }^{12}$

\section{CONCLUSÃO}

A ideia deste trabalho contrapõe a regra de que a pensão por morte rege-se pela lei vigente ao tempo do óbito do segurado.

Antes da vigência da Constituição Federal de 1988 apenas a esposa tinha direito à pensão por morte do esposo (segurado) falecido. O homem só tinha direito a esse benefício previdenciário, nessa época, se fosse inválido. No entanto, o Art. 201, V, da CF/88, para efeitos de pensão por morte, igualou homens e mulheres em direitos.

Assim, um dos entendimentos acerca da matéria é no sentido de que a norma constitucional seria de eficácia limitada, dependendo de lei para ser aplicada. Então, somente com a edição da Lei 8.213/91, que incluiu no rol de dependentes o marido não-inválido, dar-se-ia aplicabilidade à norma trazida pela Constituição, ou seja, se a esposa (segurada da Previdência Social) faleceu antes da entrada em vigor da Lei 8.213/91, mas após a Constituição Federal, o seu esposo não-inválido não teria direito ao benefício da pensão por morte.

No entanto, entendemos que o Artigo 201 da Constituição é de eficácia plena. E, qualquer interpretação em outro sentido, criaria situação discriminatória em razão do sexo, o que é vedado pela Constituição Federal. O Art. 5. ${ }^{\circ}$ I da Carta Magna refere ainda que homens e mulheres são iguais em direitos e deveres. Desse modo, a igualdade constitucional deveria ter apli- 
cação imediata, não sendo possível, a partir da entrada em vigor da Constituição Federal de 1988, qualquer aplicação de lei que tivesse tratamento desigual.

A regra de interpretação do Direito Previdenciário, que remete à aplicação da lei vigente na data do óbito para concessão da pensão por morte, não está prevista na lei; portanto, não seria possível dar maior valor a essa construção doutrinária do que à própria Constituição, ou seja, não se pode admitir que uma regra de interpretação se sobreponha à lei máxima.

As leis e regras devem ser lidas de acordo com o texto da Constituição, considerando ser ela a diretriz de todo ordenamento jurídico. A partir da sua entrada em vigor, não se admite a perpetuação da desigualdade entre homens e mulheres, não devendo ser aplicada a lei ou a regra que contemple fator discriminatório.

Além disso, o princípio constitucional da dignidade da pessoa humana, princípio de valor supremo e que abrange em seu conteúdo todos os direitos fundamentais, veda qualquer discriminação, considerando que as pessoas devem ser respeitadas, pois reconhece que todos somos iguais em dignidade.

Para reforçar a ideia da concessão da pensão por morte ao viúvo nãoinválido, após a promulgação da Constituição e antes da edição da Lei 8.213/91, importante trazer a baila que a atual Carta Magna, no Capitulo VII, ao reconhecer a proteção especial do Estado em relação à família, consagrou a absoluta igualdade entre cônjuges (homem e mulher) e filhos (Artigo 226).

Por fim, considerando que a pensão por morte é o benefício devido aos dependentes em caso de falecimento do segurado, sendo prestação continuada, de caráter substitutivo, visando a suprir, ou pelo menos minimizar, a falta dos que supriam as necessidades dos dependentes (ROCHA e JÜNIOR, 2006, p. 283) e que a CF contemplou expressamente a igualdade entre homens e mulheres, entendemos que, se óbito da segurada (esposa) tiver ocorrido após a entrada em vigor da Constituição, mesmo que antes da edi- 
ção da Lei 8.213/91, o esposo (homem) teria direito à pensão por morte, mesmo não sendo inválido.

\section{NOTAS}

1. Art. 5.": "Todos são iguais perante a lei, sem distinção de qualquer natureza, garantindo-se aos brasileiros e aos estrangeiros residentes no País a inviolabilidade do direito à vida, à liberdade, à igualdade, à segurança è à propriedade, nos termos seguintes (...)”.

2. Preâmbulo da Constituição Federal: "Nós, representantes do povo brasileiro, reunidos em Assembléia Nacional Constituinte para instituir um Estado Democrático, destinado a assegurar o exercício dos direitos sociais e individuais, a liberdade, a segurança, o bemestar, o desenvolvimento, a igualdade e a justiça como valores supremos de uma sociedade fraterna, pluralista e sem preconceitos, fundada na harmonia social e comprometida, na ordem interna e internacional, com a solução pacífica das controvérsias, promulgamos, sob a proteção de Deus, a seguinte CONSTITUIÇÃO DA REPÚBLICA FEDERATIVA DO BRASIL".

3. AC 00875659019994039999 , TRF da 3. ${ }^{a}$ Região. Quinta Turma. Relatora: juíza convocada Daldice Santana. Data da decisão: 24/06/2002.

4. TRF 4. ${ }^{a}$ Região, APELAÇÃO CÍVEL n. ${ }^{\circ}$ 0002661-90.2011.404.9999/PR, Quinta Turma, Relator: Juiz Federal LORACI FLORES DE LIMA, Data da decisão: 19/04/2011.

5.PREVIDENCIÁRIO. PEDIDO DE UNIFORMIZAÇÃO. JURISPRUDÊNCIA DOMINANTE DO SUPERIOR TRIBUNAL DE JUSTIÇA. PENSÃO POR MORTE. VIÚVO DE SEGURADA, NÃO INVÁLIDO. ÓBITO OCORRIDO ANTES DA EDIÇÃO DA LEI n. ${ }^{\circ} 8.213 / 91$. 1 . O posicionamento adotado pela Turma de origem contrariou a jurisprudência dominante do SUPERIOR TRIBUNAL DE JUSTIÇA, que entende que o viúvo de segurada, não inválido, não faz jus à pensão por morte, caso o óbito tenha ocorrido antes da edição da Lei n. ${ }^{\circ} 8.213 / 91$. 2. Ocorre que a legislação anterior apenas contemplava, como dependente da segurada, o viúvo inválido e a extensão do benefício ao mesmo, por força da isonomia, não pode ser deferida, de modo automático, em razão do advento da nova ordem constitucional, por não se cuidar de regra auto-aplicável. 3. Este é o entendimento do SUPREMO TRIBUNAL FEDERAL, que também teve a oportunidade de apreciar a matéria, adotando o mesmo ponto de vista que prevaleceu no SUPERIOR TRIBUNAL DE JUSTIÇA. 4. Pedido de uniformização conhecido e provido.

6. TRF4, 6. ${ }^{a}$ Turma. Apelação cível 2000.71.00.9347-0/RS. Relator: João Batista Pinto Silveira. Data da decisão: 27/07/2005.

7. Site da Previdência Social: www.previdencia.gov.br. Data da pesquisa: 10/09/2012. 
8. Apelação Cível n. ${ }^{\circ} 70033928516$, TJ/RS, Vigésima Primeira Câmara Cível, Data de Julgamento: $17 / 03 / 2010$

9. Apelação Cível n. ${ }^{\circ} 70022556302$, Quarta Câmara Cível, Tribunal de Justiça do RS, Relator: Alexandre Mussoi Moreira, Julgado em 26/03/2008.

10. Embargos Infringentes n. ${ }^{\circ}$ 599212057, Primeiro Grupo de Câmaras Cíveis, Tribunal de Justiça do RS, Relator: Leo Lima, Julgado em 18/06/1999.

11. Site do STF. Pesquisa de jurisprudência. Data da consulta: 18/07/2017.

12. STF, Recurso Extraordinário 433135/MG, Relator: Min. Marco Aurélio. Data da publicação: 16/09/2008.

\section{REFERÊNCIAS BIBLIOGRÁFICAS}

BONAVIDES, Paulo. Curso de Direito Constitucional. 11. a edição, revista, atualizada e ampliada. São Paulo: Malheiros, 2001.

CASTRO, Carlos Alberto Pereira de; LAZZARI, João Batista. Manual de Direito Previdenciário. 11 ed. Florianópolis: Conceito Editorial, 2009.

CORREIA, Marcus Orione Gonçalves; CORREIA, Érica Paula Barcha. Curso de Direito da

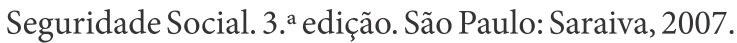

DERZI, Heloísa Hernandez. Os beneficiários da pensão por morte. Regime Geral de Previdência Social. São Paulo: Lex Editora, 2004.

DIAS, Eduardo Rocha, José Leandro Monteiro de Macedo. Curso de Direito Previdenciário. São Paulo: Método, 2008.

DUARTE, Marina Vasques. Direito Previdenciário. Sério Concursos. 3. a ed. Porto Alegre: Verbo Jurídico, 2004, 255 p.

MARTINEZ, Wladimir Novaes. Curso de Direito Previdenciário. Tomo II: Previdência

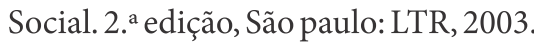

MARTINS, Sérgio Pinto. Direito da Seguridade Social. Custeio da Seguridade Social. Benefícios. Acidente do Trabalho. Assistência Social. Saúde. 24. ${ }^{a}$ edição. São paulo: Atlas, 2007.

MELLO, Celso Antônio Bandeira de. Conteúdo jurídico do princípio da igualdade. 3. ${ }^{\mathrm{a}}$

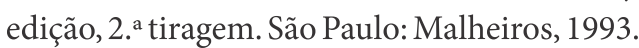

MORAES, Alexandre de. Direito Constitucional. 25. a ed., São Paulo: Atlas, 2010, 922 p.

RAMALHO, Marcos de Queiroz. A pensão por morte no Regime Geral da Previdência 
Social. São Paulo: LTr, 2006.

RIBEIRO, Júlio César Garcia. A Previdência Social no Regime Geral da Constituição Brasileira, A reforma implementada pela Emenda 20/98 e os novos rumos. Editora LTR, São Paulo: 2001.

ROCHA, Daniel Machado da; JÙNIOR, José Paulo Baltazar. Comentários à Lei de Previdência Social. 6. ${ }^{a}$ ed. Rev. Atual. Porto Alegre, Livraria do Advogado, Ed. Esmafe, 2006, 502 p.

ROCHA, Daniel Machado da. Comentários à Lei de benefícios da Previdência Social. Daniel Machado da Rocha, José Paulo Baltazar Júnior. 9.a ed. Rev. Atual., Porto Alegre: Livraria do Advogado, Editora: Esmafe, 2009, 516 p.

SANTOS, Marisa Ferreira dos. Direito Previdenciário. 5. ${ }^{a}$ ed. São Paulo: Saraiva, 2009 (Coleção Sinopses Jurídicas; vol. 25, 244 p.

Portal da Justiça Federal. Disponível em: <http://www.jf.jus.br/cjf>

Site do STF. Disponível em: <www.stf.gov.br>

Site do TRF4. Disponível em <www.trf4.jus.br>

Site do TJ/RS. Disponível em <www.tj.rs.jus.br>

Site da Presidência da República Federativa do Brasil. Disponível em: $<$ www.presidencia.gov.br >

Site da Previdência Social. Disponível em: <www.previdencia.gov.br $>$. 